\title{
DISTRIBUTION OF NUCLEAR RECEPTORS FOR STEROID HORMONES IN THE HUMAN BRAIN: A PRELIMINARY STUDY
}

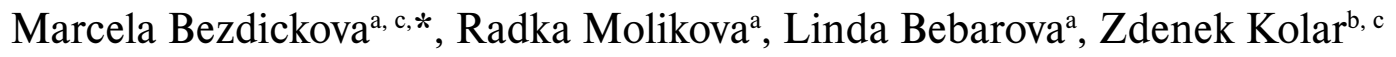 \\ ${ }^{a}$ Department of Anatomy, Faculty of Medicine and Dentistry, Palacký University, Olomouc, Czech Republic \\ ${ }^{b}$ Department of Pathology, Faculty of Medicine and Dentistry, Palacký University, Olomouc, Czech Republic \\ c Laboratory of Molecular Pathology, Faculty of Medicine and Dentistry, Palacký University, Olomouc \\ *e-mail:xbezdick@yahoo.co.uk
}

Received: April 27, 2007; Accepted: May 15, 2007

Key words: Estrogen receptor/Androgen receptor/Progesterone receptor/Brain/Human immunohistochemistry

Background: Expression of the nuclear steroid hormone receptors (SHR) within certain parts of the human brain has been described by many authors. However, a comprehensive analysis of SHR expression in the human brain still has not been performed.

Aim: To investigate the expression of SHR in different anatomical areas of the brain, especially within the neocortex.

Method: Immunohistochemical expression of estrogen receptors (ER), progesterone receptors (PR) and androgen receptors (AR) in different regions of the human brain was examined.

Results: Nuclear expression of the AR was found in the mamillary body, praecentral gyrus and hippocampus of males. The same expression in analysed structures of female was not found. The expression of ER and PR was not observed.

Conclusions: The analysis revealed unexpected localization of SHR within the brain cortex, which could be the first step to the explanation of SHR action in brain as an interrelationship to function and behaviour. These results indicate on the possibility of SHR detection in post-mortal brain.

\section{INTRODUCTION}

Nuclear receptors for steroid hormones (SHR) are members of a superfamily of ligand-dependent transcription factors that mediate the steroid hormone action in target cells. SHRs are involved in reproduction and sexual biomorphysm as well as behaviour, but their proper role in aspects of brain function such as behaviour, perception, and memory is still not fully clear. Expression of AR and ER within the hypothalamus and hippocampus, as the archi-cortex structures of the human brain has been described ${ }^{1,4,5,6}$. However, their distribution relation to the brain structure, particulary in the structures of the neocortex, and during brain development still have not been fully described. The possible role of SHRs have been suggested in pathogenesis of Alzheimer disease ${ }^{4,6,8}$; their relationship to neurodegenerative diseases is also an emerging field of interest.

\section{MATERIALS AND METHODS}

Samples of human brain tissue were taken from different areas, icluding the precentral gyrus, postcentral and frontal gyruses, corpora mammillaria and hippocampus of three cadavers (the sex and age are documented in the Tab. 1). The testes, ovary and prostate were included as positive control. Immunohistochemical staining of estrogen receptors (ER), androgen receptors (AR) and progesterone receptors (PR) was performed on $10 \%$ formalin-fixed, paraffin-embedded tissue sections of the brain cortex structures. Antibodies from Dako (Denmark) against estrogen receptors (ER; ER $\alpha$ - Monoclonal Mouse Anti-Human, Clone 1D5, Code M 7047); progesterone receptors (PR; PR - Polyclonal Rabbit AntiHuman, Code A 0098); and androgen receptors (AR; AR - Monoclonal Mouse Anti-Human, Clone AR441; CSA II, code K1497) were used.

\section{RESULTS AND DISCUSSION}

Typical nuclear SHR staining was observed within the steroid hormone receptor positive tissue used as positive controls (prostate, ovary, testes). Nuclear AR staining was observed within the mamillary body, precentral gyrus and the hippocampus of tissue taken from males but not female. Mamillary bodies as well as the hippocampus are considered to be a part of the archi-cortex. These areas have already been shown to express $\mathrm{AR}^{4}$. Lorenz et al. ${ }^{7}$ (2005) observed AR positive cells in the cerebral cortex of postnatal rats where AR positivity was described in the majority of neurons. The precentral area where the $\mathrm{AR}$ was found in our investigation is the place of the true motor cortex (M1). 
Table 1. Detailed of specification of analysed samples.

\begin{tabular}{|c|c|c|c|l|}
\hline sex & $\begin{array}{c}\text { age } \\
\text { (years) }\end{array}$ & $\begin{array}{c}\text { Time of sampling after death } \\
\text { (hours) }\end{array}$ & $\begin{array}{c}\text { Control } \\
\text { tissue }\end{array}$ & \multicolumn{1}{|c|}{ Tissue sample localization } \\
\hline M & 24 & 11,5 & testes & g. preacentralis, CM, Hipp. \\
\hline F & 68 & 9,5 & ovary & g.praecentralis, g. frontalis, CM, Hipp. \\
\hline M & 53 & 3,5 & prostate & g. praecentralis, g. postcentralis, CM, Hipp. \\
\hline
\end{tabular}

CM - corpora mamillaria; Hipp. - hippocampus; g. - gyrus; M - male; F - female

Table 2. Results of immunohistochemistry.

\begin{tabular}{|c|c|c|c|c|}
\hline & \multicolumn{3}{|c|}{$\begin{array}{c}\text { SAMPLE } \\
\text { sex (M/F) /age (years) /time to removal after death (hours) }\end{array}$} \\
\hline & & M/ 24/11,5 & $\mathrm{F} / 68 / 9,5$ & $\mathrm{M} / 53 / 3,5$ \\
\hline \multirow{3}{*}{$\begin{array}{l}\text { corpora } \\
\text { mammillaria }\end{array}$} & $\mathrm{AR}$ & $+\mathbf{C}, \mathbf{N}$ & $+\mathrm{C}$ & $+\mathrm{C}, \mathrm{N}$ \\
\hline & ER & $+\mathrm{C}$ & - & $+\mathrm{C}$ \\
\hline & PR & - & $+\mathrm{C}$ & - \\
\hline \multirow[t]{3}{*}{ hippocampus } & $\mathrm{AR}$ & $+\mathrm{C}$ & $+\mathrm{C}$ & $+\mathrm{C}, \mathrm{N}$ \\
\hline & ER & $+\mathrm{C}$ & $+\mathrm{C}$ & $+\mathrm{C}$ \\
\hline & PR & - & $+\mathrm{C}$ & - \\
\hline \multirow{3}{*}{$\begin{array}{l}\text { gyrus } \\
\text { praecentralis }\end{array}$} & $\mathrm{AR}$ & $+\mathrm{C}, \mathrm{N}$ & $x$ & $+\mathrm{C}, \mathrm{N}$ \\
\hline & ER & $+\mathrm{C}$ & $x$ & $+\mathrm{C}$ \\
\hline & PR & - & $x$ & - \\
\hline \multirow{3}{*}{$\begin{array}{l}\text { gyrus } \\
\text { postcentralis }\end{array}$} & $\mathrm{AR}$ & $x$ & - & $+\mathrm{C}$ \\
\hline & ER & $x$ & $+\mathrm{C}$ & - \\
\hline & PR & $x$ & $+\mathrm{C}$ & - \\
\hline
\end{tabular}

$\mathrm{AR}$ - androgen receptors, ER - estrogen receptor, $\mathrm{PR}$ - progesterone receptors

+ N - nuclear positivity; + N, C - nuclear and cytoplasmic positivity; - - negativity;

$+\mathrm{C}$ - cytoplasmic positivity; $\times$ - not evaluated; $\mathrm{M}$ - male; $\mathrm{F}$ - female

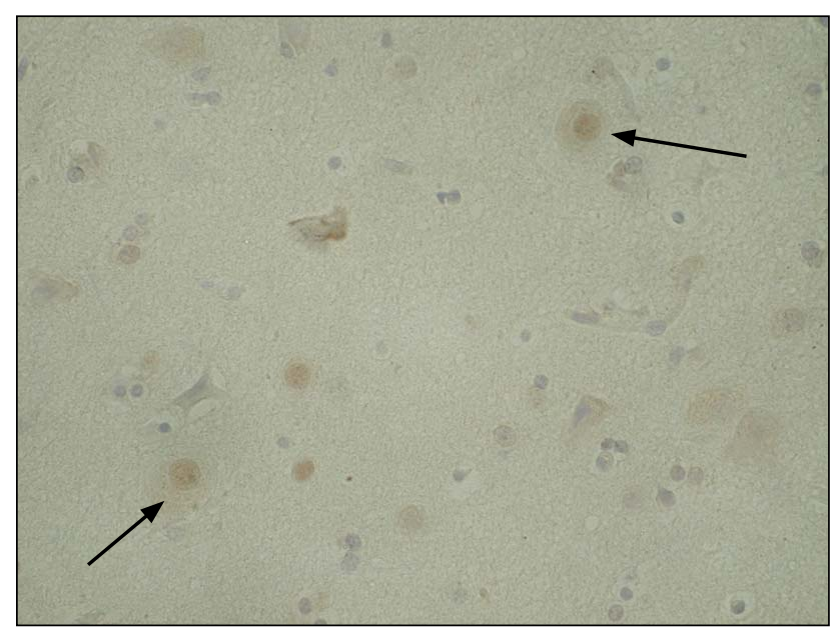

Fig. 1. Gyrus praecentralis, male, 24 years, withdrawal $11,5 \mathrm{~h}$ after death, nuclear positivity of AR, gyrus praecentralis, magn. $400 \times$.

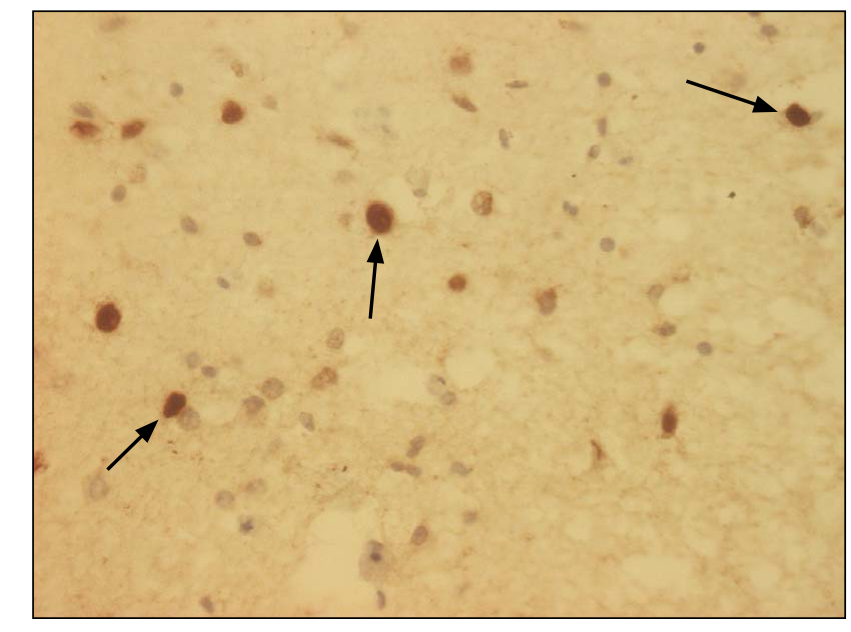

Fig. 2. Corpora mammilaria, male, 53 years; withdrawal 3,5 hours after death, nuclear positivity of AR, magn. $400 \times$. 
Considerably higher cytoplasmic positivity, particular of ER in postcentral and frontal gyrus, was observed, suggesting possible localisation of non nuclear SHR within the cytoplasm. Further studies are required to determine whether this is real or an artefact related to post-mortem changes.

Our preliminary study of the expression of SHR within the brain cortex showed unexpected results which will be the base for the follow up research.

\section{LIST OF ABBREVIATION:}

SHR - steroid hormone receptor

AR - androgen receptor

ER - estrogen receptor

$\mathrm{PR}$ - progesteron receptor

$\mathrm{F}$ - female

$\mathrm{M}$ - male

\section{ACKNOWLEDGEMENTS}

Supported by Faculty of Medicine and Dentistry guideline number LF - B3-1/2006-PN, 91110071-39 and MSM 6198959216.

\section{REFERENCES}

1. Bao AM, Hestiantoro A, Van Someren EJ, Swaab DF, Zhou JN Colocalization of corticotrophin-reelesing hormone and oestrogen receptor-alpha in the paraventricular nucleus of the hypothalamus in mood disorders. Brain 2005;128(6):1301-13.

2. Blaustein J D. Minireview: Neuronal Steroid Hormone receptors: They're Not Just for Hormones anymore. Endocrinology 2003; 145(3):1075-1081.

3. Cato AC, Nestl A, Mink S. Rapid actions of steroid receptors in cellular signaling pathways. Sci STKE 2002;138:RE9.

4. Fernandez-Guasti A, Kruijver FP, Fodor M, Swaab DF. Sex differences in the distribution of the androgen receptors in the human hypothalamus. J Comp.Neurol. 2000; 425(3):422-35.

5. Ishunina TA, van Heerikhuize JJ, Ravid R, Swaab DF. Estrogen receptor and metabolic activity in the human tuberomamillary nucleus: changes in relation to sex, aging and Alzheimer's disease. 2003

6. Ishunina TA, Kamphorst W, Swaab DF. Changes in metabolic activity and estrogen receptors in the human medial mamillary nucleus:relation to sex, aging and Alzheimer's disease. Neurobiology of Aging 2003; 24(6):817-828.

7. Lorenz B, Garcia-Segura LM, DonCarlos LL. Cellular phenotype of androgen receptor- immunoreactive nuclei in the developing and adult rat brain. J Comp Neurol 2005; 492(4):456-68.

8. Lu YP, Zeng M, Swaab DF, Ravid R, Zhou JN. Colocalization and alternation of estrogen receptor -alpha and -beta in the hippocampus in Alzheimer's disease. Hum Pathol. 2004; 35(3):275-80.

9. Perlman WR, Webster MJ, Kleinman JE, Weickert CS. Reduced glucocorticoid and receptor alpha messenger ribonucleic acid levels in the amygdale of patients with major mental illness. Biol Psychiatry 2004; 56(11):844-52.

10. Royen ME, Cunha SM, Brink MC, Mattern KA, Nigg AL, Dubbink HJ, Verschure PJ, Trapman J, Houtsmuller AB. Compartmentalization of androgen receptor protein-protein interactions in living cells. J Cell Biol 2007; 177(1):63-72. 